\title{
Expression Pattern of the Ets-related Transcription Factor Elf-1
}

\author{
Alexander G. Bassuk, Kevin P. Barton, Roshani T. Anandappa, \\ Min M. Lu, and Jeffrey M. Leiden \\ Departments of Medicine and Pathology, University of Chicago, \\ Chicago, Illinois, U.S.A. \\ Communicated by J. Leiden. Accepted April 15, 1998.
}

\begin{abstract}
Members of the Ets family of winged helix-loop-helix transcription factors play important roles in the development and function of multiple mammalian cell lineages. Elf- 1 is an Ets-related transcription factor that is expressed at high levels in $\mathrm{T}$ cells and is known to regulate the expression of several $\mathrm{T}$ cell genes, including the granulocyte-macrophage colony stimulating factor (GMCSF) gene, the interleukin-2 receptor alpha subunit (IL$2 \mathrm{R} \alpha$ ) gene, and the CD4 gene. In the studies described in this report, we have characterized the pattern of expression of Elf- 1 in the developing mouse embryo and in adult mouse tissues as well as in multiple immortalized human and murine cell lines. Elf-1 is expressed at high levels throughout thymocyte development, with equivalent levels of Elf- 1 expression seen in all subsets of maturing thymocytes and $\mathrm{T}$ cells. Somewhat surpris-
\end{abstract}

ingly, however, Elf- 1 is also expressed at high levels in epithelial cells lining the oral cavity, the lung, the CNS, and the gastrointestinal and urinary tracts as well as in the skin of the developing mouse embryo and at lower levels in the adult mouse testis and liver. Western blot analyses of a large number of immortalized cell lines demonstrated high-level Elf- 1 expression in $\mathrm{T}$ and $\mathrm{B}$ lymphocyte and macrophage cell lines as well as in two prostate carcinoma cell lines. Low-level expression was observed in fibroblasts, embryonic stem cells, and myoblasts. Taken together, our data suggest that in addition to its role in regulating $\mathrm{T}$ cell development and function, Elf- 1 may regulate gene expression in the $B$ cell and myelomonocytic lineages, as well as in multiple epithelial cell types during murine embryonic development.

\section{Introduction}

The Ets transcription factors are a large family of winged helix-loop-helix DNA binding proteins that recognize purine-rich motifs centered around the core sequence, GGA A/T (1-8). Ets proteins are expressed in a wide variety of species including nematodes, sea urchins, flies, frogs, birds, mice, and humans. Invertebrate Ets proteins are both positive and negative regulators of development, as in vulval cell-fate determination in Caenorhabditis elegans, and steroid-

Address correspondence and reprint requests to: Dr. Jeffrey M. Leiden, Department of Medicine, University of Chicago, 5841 S. Maryland Ave., Chicago, IL 60637, U.S.A. Phone: (773) 702-1919; Fax: (773) 702-1385; E-mail: jleiden@ medicine.bsd.uchicago.edu induced metamorphosis, photoreceptor ontogeny, and oogenesis in Drosophila (9-16). At least 17 different mammalian Ets proteins have been described to date. Many of these proteins are expressed in a cell lineage-restricted pattern, and some, but not all, display oncogenic potential (7). Recent gene targeting studies (17-19) have demonstrated important roles for two Ets proteins, Ets- 1 and PU.1, in regulating the development and function of specific hematopoietic cell lineages in the mouse.

Elf- 1 is an Ets-related transcription factor that was originally cloned from a human $\mathrm{T}$ cell library by hybridization with a probe encoding the DNA binding domain (Ets domain) of the human Ets-1 cDNA (20). Subsequently, func- 
tionally important Elf-1 binding sites have identified in the transcriptional regulatory elements of multiple genes involved in T cell, B cell, and macrophage development and activation; these genes include those for interleukin-3 (IL-3) (21), IL-2 receptor alpha subunit (IL-2R $\alpha$ ) (22), granulocyte macrophage-colony stimulating factor (GM-CSF) (23), CD2 (24), CD4 (25), immunoglobulin heavy chain (IgH), terminal deoxynucleoidyltransferase (TdT) (26), c-Fes (27), and the HIV-2 LTR (28-30). In accord with these findings, Elf- 1 is known to be expressed at high levels in both normal $\mathrm{T}$ cells and immortalized $\mathrm{T}$ cell lines. However, its pattern of expression during mammalian development and its spectrum of expression in adult mammalian tissues and cell lineages have remained unknown. Such information might be expected to provide important clues as to the function of the protein, and should also be useful in interpreting the phenotype of mice with targeted mutations of the Elf-1 gene. To address these questions directly, we have analyzed the pattern of expression of Elf-1 during murine embryogenesis, in adult murine tissues, in lymphoid subsets, and in immortalized human and murine cell lines.

\section{Materials and Methods}

\section{In Situ Hybridization}

In situ hybridization was performed as described by Kuratani and co-workers (31) and by Parmacek and co-workers (32). A cDNA fragment encompassing bp 19-850 of the murine Elf-1 cDNA (33) was subcloned into EcoRI-digested pGEM7Z (Promega, Madison, WI). The resulting plasmid was transcribed in vitro using T7 or SP6 polymerase in the presence of ${ }^{35} \mathrm{~S}$-labeled UTP to generate anti-sense and sense cRNA probes, respectively. Following hybridization with either sense (control) or anti-sense Elf-1 cRNA probes, sections were processed for emulsion autoradiography, were post-stained with Hoechst 33258 , and visualized by epiflourescence and dark-field microscopy on a Zeiss Axiophot microscope.

\section{Western Blot Analysis}

Tissues (from 7-week-old CDl mice) and cell lines were lysed in NETN (20 mM Tris [pH 8.0], $100 \mathrm{mM} \mathrm{NaCl}, 1 \mathrm{mM}$ EDTA, and $0.5 \% \mathrm{NP}-40$ ), and the protein concentrations of the resulting lysates were determined using a commercially available kit (Pierce, Rockford, IL). Then $100 \mu \mathrm{g}$ of cell extract was denatured by boiling in SDSPAGE loading buffer ( $50 \mathrm{mM}$ Tris ( $\mathrm{pH} 6.8$ ), 30\% glycerol, $0.4 \%$ SDS, $0.1 \%$ bromophenol blue, and $10 \% \beta$-mercaptoethanol) and was resolved by electrophoresis in $8 \%$ SDS-containing polyacrylamide gels. Proteins were transferred to nitrocellulose membranes (34) and the resulting immunoblots were probed with a 1:500 dilution of the $\alpha$-Elf-1 monoclonal antibody (mAb) 5A3 in conjunction with a 1:3000 dilution of a commercially available horseradish peroxidase-coupled goat antibody to mouse immunoglobulin (Ig) (GIBCO BRL, Grand Island, NY). Immunoblots were developed using a commercially available kit (Amersham, Arlington Heights, IL) as described previously (34). The 5A3 $\alpha$-Elf-1 mAb was produced by immunization of $\mathrm{BALB} / \mathrm{c}$ mice with bacterial Elf-1 protein. It recognizes a Cterminal epitope of Elf- 1 and does not cross-react with other Ets proteins (B. Cobb and J. Leiden, unpublished data).

\section{Immunohistochemical Analysis}

Paraffin-embedded sections from 7-week-old $\mathrm{CDl}$ mice were baked at $60^{\circ} \mathrm{C}$ for $\mathrm{l} \mathrm{hr}$, cleared in xylene, and hydrated in descending alcohol concentrations with distilled water. The hydrated tissue sections were placed in $0.01 \mathrm{M}$ citrate buffer $(\mathrm{pH}=7.0)$. Endogenous peroxidase activity was blocked by treating sections with $3 \%$ hydrogen peroxide in methanol for $20 \mathrm{~min}$. Tissue sections were then incubated overnight at $4^{\circ} \mathrm{C}$ with an Elf- 1 -specific polyclonal antiserum (35). Immunohistochemical staining was performed on a Ventura Gen System (Ventura Medical Systems), and sections were counterstained with hematoxylin.

\section{Purification of Lymphocyte Subsets}

To purify splenic B cells, ammonium chloridelysed splenocytes from adult $\mathrm{CD} 1$ mice were subjected to combined anti-Thy- 1 and anti-CD8 plus complement depletion. Cells were then stained with fluorescent (FITC)-labeled R40-97 (antiIgM) and phycoerythrin (PE)-labeled RA3-6B2 (anti-B220) (Pharmingen, San Diego, CA). $\mathrm{IgM}^{+} / \mathrm{B}^{2} 20^{+}$positive cells were sorted on a FACStar PLUS (Becton-Dickinson, Thousand Oaks, CA). Splenic T cells from adult CDl mice were purified from red cell-depleted spleens using a mouse $\mathrm{T}$ cell enrichment column according to the manufacturer's instructions (R\&D Systems, Minneapolis, MN). The purity of the final T 
Fig. 1. Elf-1 gene expression during murine embryogenesis. In situ hybridization analyses were performed using the control Elf-l sense riboprobe $(\mathrm{A}, \mathrm{C})$ or the Elf- 1 anti-sense riboprobe $(\mathrm{B}, \mathrm{D})$ on staged $\operatorname{ED} 14(\mathrm{~A}, \mathrm{~B})$ and $\operatorname{ED} 20$ (C, D) murine embryos. Original magnification, $\times 1.25$. In the EDI 4 embryo, the Elf- 1 riboprobe hybridized (white staining) specifically to the thymus ( $\mathrm{T}$ ) (see also Fig. 2B, $D)$ and to the epithelial lining of the nose $(\mathrm{N})$, mouth (M) (see also Fig. 2B), lungs (L) (see also Fig. $2 \mathrm{C})$, and gut $(\mathrm{Gu})$ as well as to cells lining the primitive ventricles in the brain. In the ED20 embryo, the Elf-1 riboprobe hybridized specifically to the thymus $(\mathrm{T})$, mouth, lung $(\mathrm{L})$, bladder $(\mathrm{Bl})$, and the epithelial and mucosal layers of the esophagus (Eo), stomach (St) (see also Fig. 2F), small intestine (Si), and colon (Co). Lower-intensity hybridization was also observed in the skin epithelia (Se) and in the kidney $(\mathrm{K})$. Elf- 1 expression was not observed in the developing heart (He). The liver ( $\mathrm{Li}$ ), thyroid (Th), and adrenal gland (Ad) hybridized to both the anti-sense and sense probes. Note that the intense fluorescence due to erythrocytes (Er) is the result of the refractile property of these cells under dark-field microscopy and does not represent Elf-1-specific gene expression. cell populations was determined by flow cytometry using FITC-labeled 145-2Cl1 (anti-CD3). All preparations contained at least $98 \%$ CD3 $\mathrm{T}$ cells. Single positive (SP) $\mathrm{CD}^{+}$and $\mathrm{CD} 8^{+}$cells were obtained from the spleens of adult CDI mice as follows: Red cell-depleted splenocytes were stained with PE-labeled RM-4-5 (anti-CD4) or FITC-labeled 53-6.7 9 (anti-CD8) (Pharmingen, San Diego, CA) and sorted on a FACStar PLUS (Becton-Dickinson). Double positive (DP) adult CDl thymocytes were obtained by FACSsorting following staining with PE-labeled RM4-5 (anti-CD4) and FITC-labeled 53-6.7 9 (anti$\mathrm{CD} 8)$. Double negative (DN) $\left(\mathrm{CD} 4^{-} / \mathrm{CD}^{-}\right)$ thymocytes were obtained directly from the thymus of a RAG2 $2^{-1-}$ mouse, as $\mathrm{RAG}^{-1-}$ mice display a block in thymocyte development at the DN stage. Finally, $2 \times 10^{6}$ cells from each population were denatured in SDS loading buffer, resolved by electrophoresis in $8 \%$ SDS-containing polyacrylamide gels, and subjected to immunoblot analysis as described above.

\section{Results}

\section{Expression of Elf-1 during Murine Embryogenesis}

To determine the temporal and spatial patterns of expression of Elf-1 during murine development, in situ hybridization experiments were performed using an Elf-1-specific riboprobe. This probe contains nucleotides 19-850 of the murine Elf-1 cDNA, including 301 nucleotides of 5' untranslated sequence and 530 nucleotides from the N-terminal region of the Elf-1 protein (33). This sequence does not show significant homology to any previously reported nucleotide sequence as determined by low-stringency homology searches of GenBank and does not hybridize to other known Ets-related mRNAs.
At embryonic days (ED) 8-10, Elf- 1 is expressed at very low levels diffusely throughout the developing mouse embryo (data not shown). In contrast, EDl 4 mouse embryos display highlevel Elf-1 expression in both the cortical and medullary areas of the developing thymus (Figs. 1B and 2B, D). In addition, high-level Elf-1 expression was observed in epithelial cells lining the nose $(\mathrm{N})$, mouth $(\mathrm{M})$, lungs $(\mathrm{L})$, and gut $(\mathrm{Gu})$ (Figs. IB and 2B, D), as well as in cells lining the primitive ventricles of the CNS.

At ED20, Elf- 1 continued to be expressed at high levels in the thymus and in epithelial cells of the nose, mouth, gut (esophagus, stomach, small intestine, and colon), and lung (Figs. 1C, D and $2 \mathrm{E}, \mathrm{F})$. In addition, high-level Elf-1 expression was detected in the epithelial cells of the kidney and bladder as well as in the skin (Fig. 1C, D). Elf- 1 expression was also detected in the developing spleen (data not shown). In contrast, Elf- I expression was not detected in developing skeletal muscle, smooth muscle, heart, or brain (Fig. 1B, D). We could not accurately assess the levels of Elf- 1 expression in the developing liver, thyroid, or adrenals because the sense and antisense probes hybridized equally well to these organs. Taken together, these results demonstrated that during murine embryonic development, Elf- 1 is preferentially expressed in the lymphoid organs (thymus and spleen) and in a wide variety of epithelial cells, including those lining the gastrointestinal, urogential, and respiratory tracts, the CNS, and the skin.

\section{Expression of Elf-1 in Adult Mouse Tissues}

To determine the tissue distribution of Elf-1 protein expression in the adult mouse, cell extracts obtained from adult murine tissues were subjected to Western blot analysis using a monoclo- 

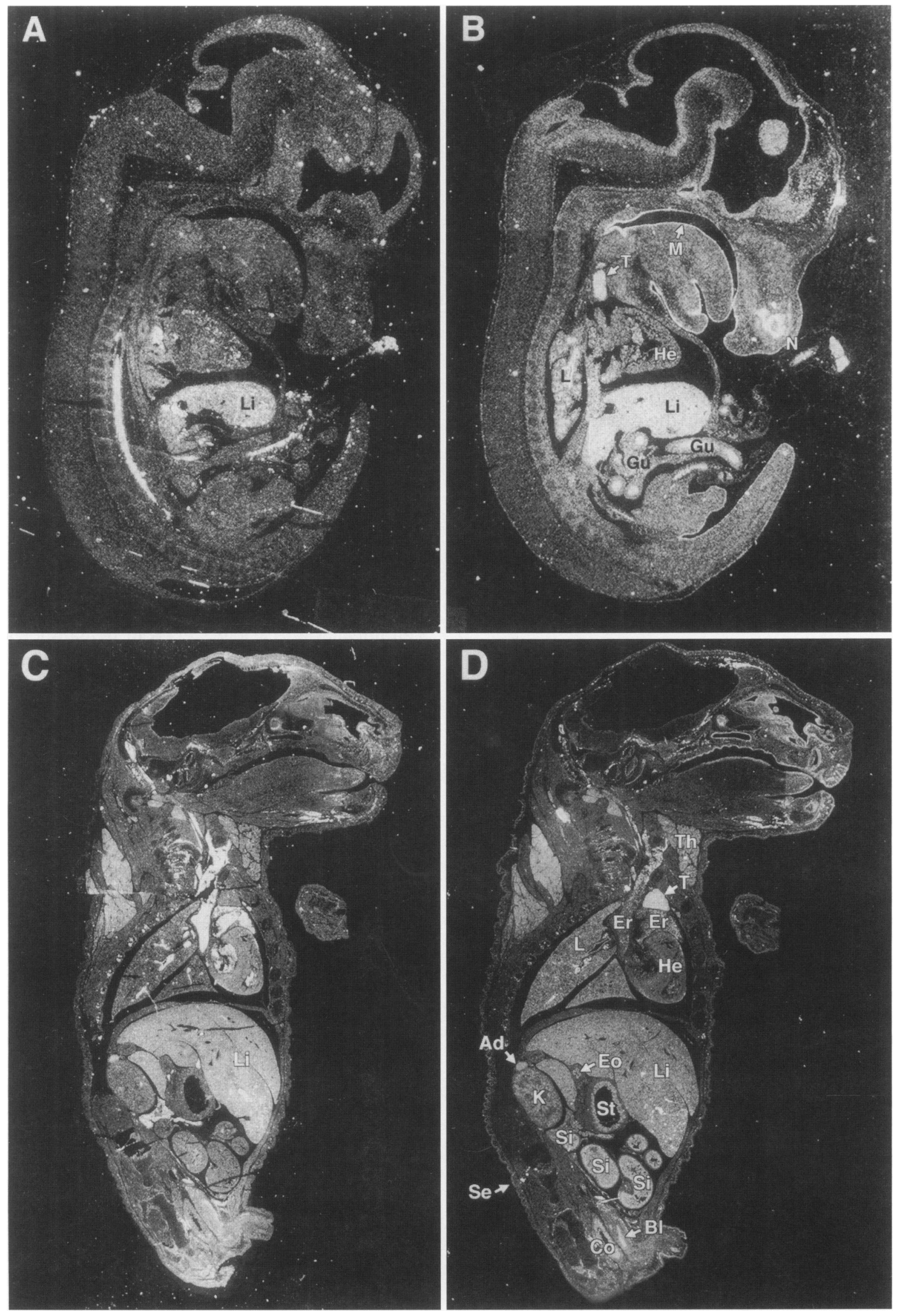
nal antibody that specifically recognizes a nonconserved C-terminal epitope of Elf- 1 ( $\alpha$-Elf- 1 $\mathrm{mAb}$ ). As shown in Figure 3, Elf-1 (which migrates as a $97-\mathrm{kD}$ doublet by SDS-PAGE) is expressed most abundantly in adult hematopoietic tissues, including thymus, spleen, and bone marrow. Elf- 1 is expressed at moderate levels in the adult testis, liver, kidney, small intestine, and bladder and at very low levels in the adult heart and lung. Low levels of Elf- 1 protein were also detected in the adult ovary and oviducts (data not shown). Elf-1 protein was undetectable in adult skeletal muscle and brain. Identical patterns of Elf- 1 expression were observed in Western blotting experiments using a second $\mathrm{mAb}$ that recognizes an $\mathrm{N}$-terminal epitope of the Elf-1 protein (data not shown).

To further demonstrate the expression of the Elf- 1 protein in adult mouse tissues, sections of adult mouse gut and skin were subjected to immunohistochemical analysis using a polyclonal antibody to Elf-1 (35). Elf-1 protein was detected at high levels in epithelial cell of the gut and skin (Fig. 4A, B). Immunohistochemical staining of Elf-1 protein was also observed in embryonic mouse thymus, gut, and skin (data not shown).

\section{Expression of Elf-1 in Lymphocyte Subsets}

To further explore the patterns of Elf-1 expression during $\mathrm{T}$ cell development, we performed Western blot analyses on extracts from purified $\mathrm{T}$ cell subsets, including immature $\mathrm{CD} 4^{-} \mathrm{CD} 8^{-}$ (DN) thymocytes, more mature $\mathrm{CD} 4^{+} \mathrm{CD} 8^{+}$(DP) thymocytes, and mature $\mathrm{CD}^{+}{ }^{+} \mathrm{CD} 8{ }^{-}$or $\mathrm{CD}^{+} \mathrm{CD}^{-}$(SP) thymocytes and resting splenic $\mathrm{T}$ cells (Fig. 5). Equivalent levels of Elf-1 expression were detected in each of the $\mathrm{T}$ cell subsets. In addition, Elf- 1 was found to be expressed at a similar level in purified mature $\operatorname{IgM}^{+} \mathrm{B} 220^{+} \mathrm{B}$ cells (Fig. 5). Thus, Elf- 1 is expressed in both normal murine $\mathrm{B}$ and $\mathrm{T}$ cells, and its levels of expression are relatively constant throughout thymocyte ontogeny.

\section{Expression of the Elf-1 Protein in Human and Murine Cell Lines}

To more precisely determine the pattern of Elf- 1 expression in specific cell lineages, we assayed Elf- 1 expression by Western blot analysis in a large number of immortalized murine and human cell lines (Fig. 6). As expected, Elf-1 was expressed at high levels in all of the $\mathrm{T}$ and $\mathrm{B}$ cell lines tested including the Jurkat $\mathrm{T}$ cell lymphoma
(Fig. 6, lane 1), the B and T lymphoblast hybrid CEMT.1 (Fig. 6, lane 3), the IL-2-dependent cytotoxic T cell line CTLL-2 (Fig. 6, lane 14), the T cell lymphoma EL-4 (Fig. 6, lane 13), the B cell lymphomas clone 12 and Bcl-1 (Fig. 6, lanes 2 and 4), and the plasmacytoma P815 (Fig. 6, lane 15). In addition, high-level Elf-1 expression was observed in other hematopoietic cell lineages including the monocyte cell lines U937 (Fig. 6, lane 5 ) and HL-60 (Fig. 6, lane 6), and the erythroleukemia cell line K562 (Fig. 6, lane 7). Somewhat surprisingly, Elf- 1 was also expressed at high levels in two cell lines derived from prostatic adenocarcinomas, PC-3 and LNCaP (Fig. 6, lanes 11, 12). Much lower but detectable levels of Elf-1 protein were found in other cell lines including the SAOS and U2OS osteosarcomas (Fig. 6, lanes 8, 9), HeLa cells (Fig. 6, lane 10), the fibroblast cell lines NIH-3T3 (Fig. 6, lane 16) and STO (Fig. 6, lane 18), the skeletal muscle cell line $\mathrm{C} 2 \mathrm{C} 12$ (Fig. 6, lane 17), and the murine embryonic stem cell line CCE (Fig. 6, lane 19). - Taken together, these data were consistent with the Western blot and in situ hybridization analyses of normal mouse tissues demonstrating that Elf- 1 is expressed at low levels in many different cell lineages and at high levels in hematopoietic cells (B cells, $\mathrm{T}$ cells, and macrophages) as well as in cells of prostatic origin.

\section{Discussion}

In the studies described in this report we have characterized the spatial and temporal patterns of expression of the Ets-related transcription factor Elf-1. Consistent with previous studies, our data demonstrate high-level Elf-1 expression in thymocytes and T cells. Moreover, levels of Elf- 1 expression were shown to be relatively constant throughout thymocyte differentiation. Highlevel Elf- 1 expression was also demonstrated in mature B cells. Somewhat surprisingly, however, we found that Elf-1 expression is not limited to the lymphoid cell lineages and that Elf- 1 is in fact expressed in cell lineages that are derived from all three embryonic germ layers. High-level Elf-1 expression was detected in macrophages and in multiple developing epithelial cells, including those lining the respiratory, gastrointestinal, and urogenital tracts as well as those in the skin and in two different prostatic adenocarcinoma cell lines. Moreover, low-level Elf- 1 expression was seen in many immortalized human and murine cell lines. These data have potential implications 

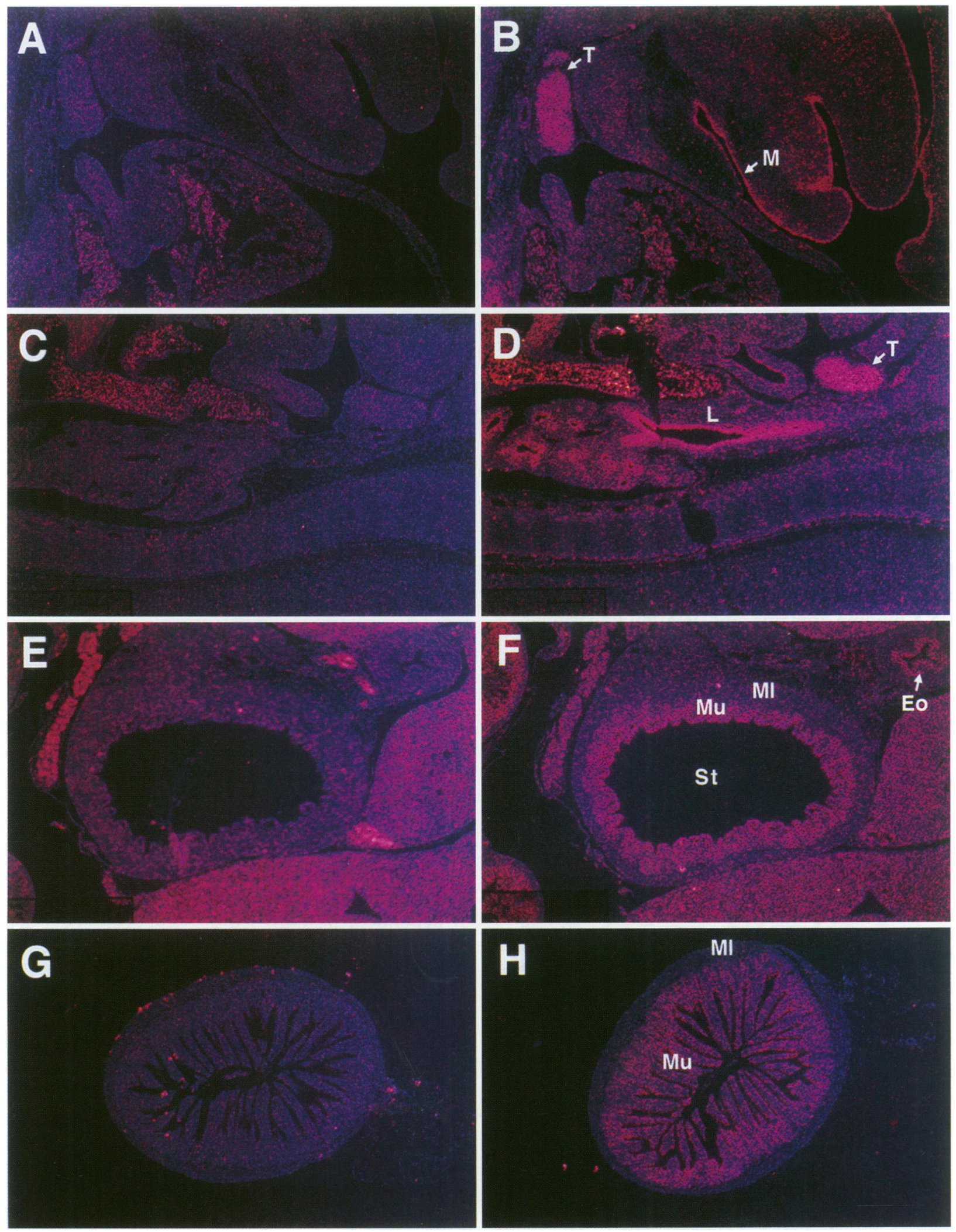

Fig. 2. Epifluorescent resolution of Elf-1 gene expression in ED14.5 and ED20 embryos and in the adult gut. In situ hybridization analyses were performed using the control Elf-I sense riboprobe (A, C, E, G) or the Elf-1 anti-sense riboprobe (B, D, $\mathrm{F}, \mathrm{H})$ on staged ED 14.5 day embryos (A-D), on

ED20 embryos $(E, F)$, or on adult gut $(G, H)$. Original magnification, $\times 20(A-F)$ and $\times 5(G, H)$. In the ED20 embryo, Elf- 1 hybridized (red staining) to the

thymus $(T)$ epithelial lining of the mouth $(M$, arrow), epithelial lining of the lung (L), and epithelial and mucosal $(\mathrm{Mu})$ layers of the stomach $(\mathrm{St})$ and esophagus (Eo, arrow), but not to the muscular layers $(\mathrm{Ml})$ of the stomach. In the adult gut section, Elf-1 hybridized to the epithelial and mucosal $(\mathrm{Mu})$ layers of adult gut, but not to the muscular layer (Ml). 


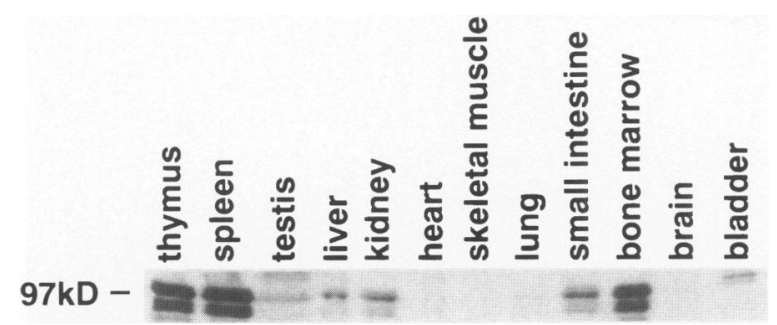

Fig. 3. Elf-1 expression in adult murine tissues. Protein extracts from adult murine tissues were fractionated by SDS-PAGE and analyzed by protein immunoblot analysis with an $\alpha$-Elf-1 mAb. The 97 kilodalton $(\mathrm{kD})$ marker is shown to the left of the autoradiogram.

for understanding the function of Elf- 1 in both embryonic and adult tissues.

Recently, four mammalian Elf-1 related genes, Elf-2 (36), NERF (37), MEF (38), and Elf-3/ESE-1/ESX/JEN, have been isolated. All four Elf-1-related proteins share highly related DNA binding domains and DNA binding properties. The initial descriptions of these related tran-

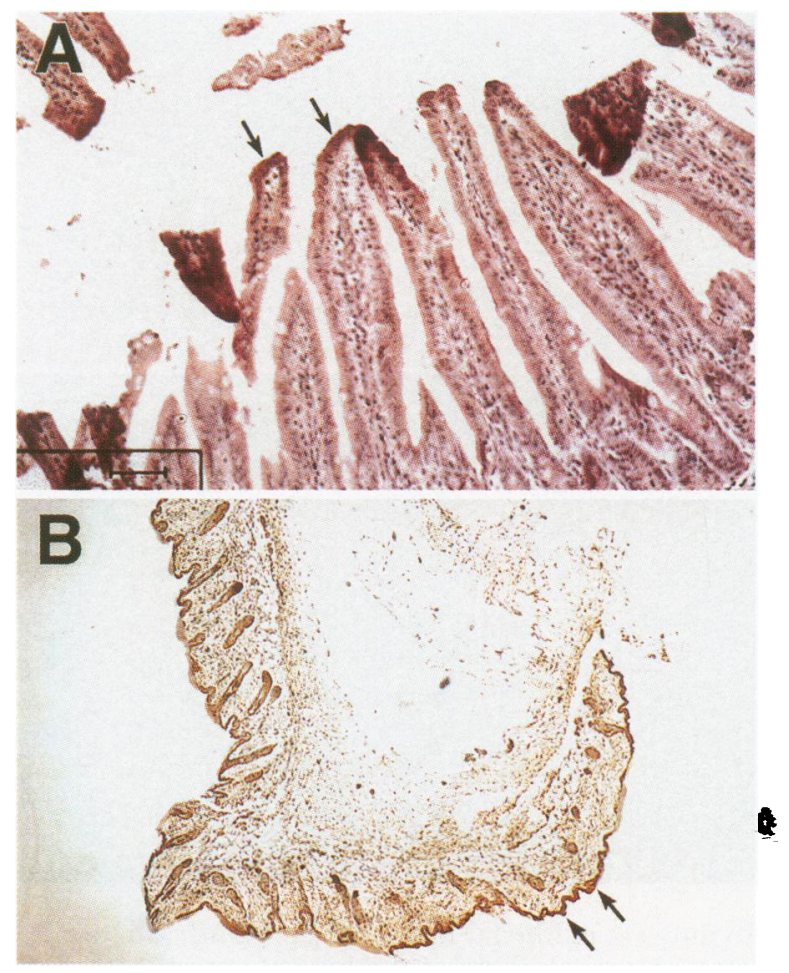

Fig. 4. Immunohistochemical analysis of Elf-1 expression using an anti-Elf-1 polyclonal antiserum. Adult mouse gut (A) and skin (B). Note Elf- 1 staining in the epithelial lining of the gut lumen (A, arrows) and in the epithelial layer of skin (B, arrows).

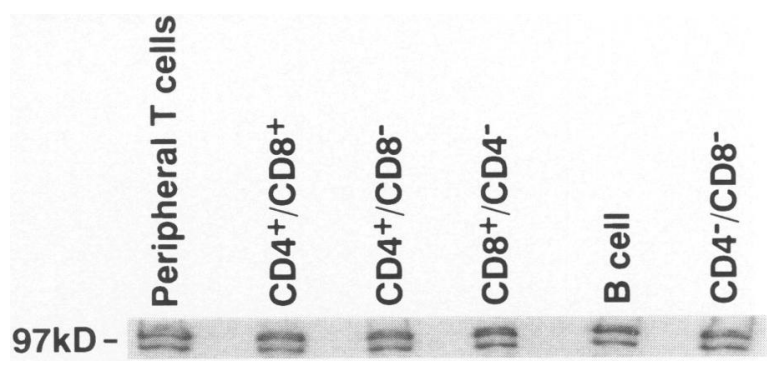

Fig. 5. Expression of the Elf-1 protein in lymphocyte subsets. Protein extracts from purified lymphocyte subsets were fractionated by SDS-PAGE and analyzed by protein immunoblot analysis with an $\alpha$-Elf- $1 \mathrm{mAb}$. The $97 \mathrm{kD}$ marker is shown to the left of the autoradiogram.

scription factors suggest that their expression patterns are distinct but overlapping. Importantly, expression of the Elf-1-related factor Elf3/ESE-1/ESX is restricted to epithelial cells (3942). Moreover, potential Elf-family binding sites have recently been identified in the promoters of several epithelial cell-restricted genes including Maspin (43) and SPRR2A (40). Taken together with our description of Elf-1 expression in multiple epithelial cell lineages, these results suggest an important role for the Elf subfamily of transcription factors in the regulation of epithelialspecific gene expression.

We have reported previously that the activity of Elf- 1 in $T$ cells is regulated by interactions with the retinoblastoma protein and that these interactions in turn are regulated in a cell cycledependent fashion. Thus, it has been suggested that Elf-1 may serve as an important regulator of cell cycle-specific gene expression. In this regard, it is of interest that the terminal differentiation of $\mathrm{T}$ cells, B cells, macrophages, and epithelial cells (each of which expresses high levels of Elf-1) are all tightly regulated in relation to cell proliferation. Thus, for example, proliferating undifferentiated epithelial cells in the crypts of the gut or the basal layers of the skin withdraw from the cell cycle as they differentiate and migrate to form the surface epithelium $(44,45)$. Conversely, resting $\mathrm{T}$ and $\mathrm{B}$ cells are both proliferatively and transcriptionally quiescent until activated by an appropriate antigenic peptide, at which time they simultaneously proliferate and coordinately express a set of activation-specific genes. Thus, it is tempting to speculate that Elf-1 may function in some way to coordinate differentiation-specific gene expression and cell-cycle progression in these diverse cell lineages. It should be em- 


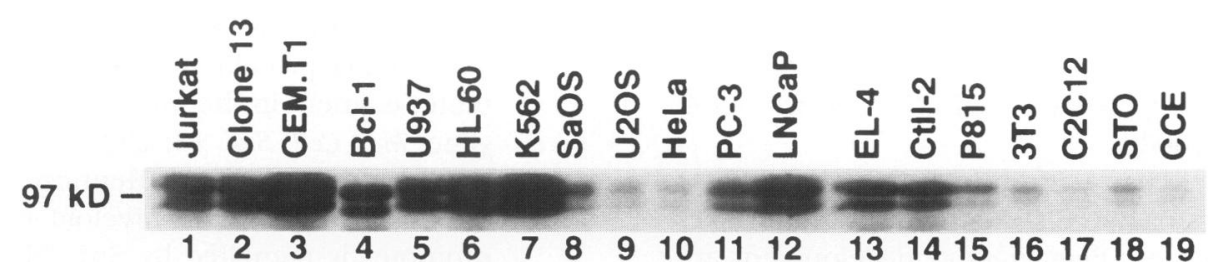

Fig. 6. Expression of the Elf-1 protein in human and murine cell lines. Protein extracts from the indicated cell lines were fractionated by SDS-
PAGE and analyzed by protein immunoblot analysis with an $\alpha$-Elf- 1 mAb. The $97 \mathrm{kD}$ marker is shown to the left of the autoradiogram. phasized that it has thus far been difficult to demonstrate the transcriptional activity of Elf-1 in transient transfection assays and it therefore remains unclear if Elf- 1 serves predominately as a positive or negative regulator of lymphoid gene expression. Moreover, the activity of Elf- 1 is regulated both by interactions with other proteins, such as Rb (34), AP1 (46), and NF- $\kappa$ B/NFAT (47), and by phosphorylation (A. G. Bassuk and J. Leiden, unpublished results). Thus, the expression of the gene in a particular cell lineage as assayed by Western blot or in situ hybridization analyses does not necessarily correlate with its transcriptional activity. Given these findings, it will be important to correlate the transcriptional activity of Elf-1 with both the proliferative and differentiation states of various epithelial and lymphoid cells.

The simultaneous expression of multiple Etsrelated transcription factors in single cell lineages has complicated studies designed to elucidate the role of individual Ets proteins in mammalian development and cell biology. For example, at least six different Ets proteins are expressed in $\mathrm{T}$ cells, and several of these proteins are often capable of binding to a single putative Ets target site. In an attempt to circumvent this problem, gene targeting has been used to more precisely characterize distinct roles for specific Ets proteins in mammalian hematopoiesis. We have recently produced a targeted mutation of the murine Elf- 1 gene and transmitted this mutation through the germ line. Our findings concerning the patterns of Elf- 1 expression in normal mice should facilitate the interpretation of the phenotypes of these Elf-1-deficient animals.

\section{References}

1. Karim FD, Urness LD, Thummel CS, et al. (1990) The ETS-domain: a new DNA-binding motif that recognizes a purine-rich core DNA sequence. Genes Dev. 4: 1451-1453.
2. Nye JA, Petersen JM, Gunther CV, Jonsen MD, Graves BJ. (1992) Interaction of murine Ets-1 with GGA-binding sites establishes the ETS domain as a new DNA-binding motif. Genes Dev. 6: 975-990.

3. Wasylyk B, Hahn SL, Giovane A. (1993) The Ets family of transcription factors [Review]. Eur. J. Biochem. 211: 7-18 [published erratum appears in Eur. J. Biochem. 1993 215: 907].

4. Liang H, Mao X, Olejniczak ET, et al. (1994) Solution structure of the ets domain of Fli-1 when bound to DNA. Nat. Struct. Biol. 1: 871-875.

5. Liang H, Olejniczak ET, Mao X, et al. (1994) The secondary structure of the ets domain of human Fli-l resembles that of the helix-turn-helix DNAbinding motif of the Escherichia coli catabolite gene activator protein. Proc. Natl. Acad. Sci. U.S.A. 91: 11655-11659.

6. Werner $\mathrm{MH}$, Clore $\mathrm{M}$, Fisher $\mathrm{CL}$, et al. (1995) The solution structure of the human ETS1-DNA complex reveals a novel mode of binding and true side chain intercalation. Cell 83: 761-771.

7. Bassuk A, Leiden J. (1996) The role of Ets transcription factors in the development and function of the mammalian immune system. Adv. Immunol. 64: 65-104.

8. Kodandapani R, Pio F, Ni C, et al. (1996) A new pattern for helix-turn-helix recognition revealed by the PU.1 Ets-domain-DNA complex. Nature 380: $456-460$.

9. Burtis KC, Thummel CS, Jones CW, Karim FD, Hogness DS. (1990) The Drosophila 74EF early puff contains $E 74$, a complex ecdysone-inducible gene that encodes two ets-related proteins. Cell 61: 8599.

10. Urness LD, Thummel CS. (1990) Molecular interactions within the ecdysone regulatory hierarchy: DNA binding properties of the Drosophila ecdysone-inducible E74A protein. Cell 63: 47-61.

11. Pribyl LJ, Watson DK, Schulz RA, Papas TS. (1991) D-elg, a member of the Drosophila ets gene family: sequence, expression and evolutionary comparison. Oncogene 6: 1175-1 183.

12. Lai ZC, Rubin GM. (1992) Negative control of photoreceptor development in Drosophila by the product of the yan gene, an ETS domain protein. Cell 70: 609-620. 
13. Schulz RA, The SM, Hogue DA, Galewsky S, Guo Q. (1993) Ets oncogene-related gene Elg functions in Drosophila oogenesis. Proc. Natl. Acad. Sci. U.S.A. 90: 10076-10080.

14. O'Neill EM, Rebay I, Tjian R, Rubin GM. (1994) The activities of two Ets-related transcription factors required for Drosophila eye development are modulated by the Ras/MAPK pathway. Cell 78: 137-147.

15. Beitel GJ, Tuck S, Greenwald I, Horvitz HR. (1995) The Caenorhabditis elegans gene lin-1 encodes an ETS-domain protein and defines a branch of the vulval induction pathway. Genes Dev. 9: 3149-3162.

16. Fletcher JC, Thummel CS. (1995) The Drosophila E74 gene is required for the proper stage- and tissue-specific transcription of ecdysone-regulated genes at the onset of metamorphosis. Development 121: 1411-1421.

17. Scott EW, Simon MC, Anastasi J, Singh H. (1994) Requirement of transcription factor PU.1 in the development of multiple hematopoietic lineages. Science 265: 1573-1577.

18. Bories JC, Willerford DM, Grevin D, et al. (1995) Increased T-cell apoptosis and terminal B-cell differentiation induced by inactivation of the Ets-1 proto-oncogene. Nature 377: 635-638.

19. Muthusamy N, Barton K, Leiden JM. (1995) Defective activation and survival of $\mathrm{T}$ cells lacking the Ets-1 transcription factor. Nature 377: 639642.

20. Thompson CC, Brown TA, McKnight SL. (1991) Convergence of Ets- and notch-related structural motifs in a heteromeric DNA binding complex [see comments]. Science 253: 762-768.

21. Gottschalk LR, Giannola DM, Emerson SG. (1993) Molecular regulation of the human IL-3 gene: inducible $\mathrm{T}$ cell-restricted expression requires intact AP-1 and Elf- 1 nuclear protein binding sites. J. Exp. Med. 178: 1681-1692.

22. John S, Reeves RB, Lin JX, et al. (1995) Regulation of cell-type-specific interleukin-2 receptor alpha-chain gene expression: potential role of physical interactions between Elf-1, HMG-I(Y), and NF-kappa B family proteins. Mol. Cell. Biol. 15: 1786-1796.

23. Wang CY, Bassuk AG, Boise LH, et al. (1994) Activation of the granulocyte-macrophage colony-stimulating factor promoter in $\mathrm{T}$ cells requires cooperative binding of Elf-1 and AP-1 transcription factors. Mol. Cell. Biol. 14: 1153-1159.

24. Wotton D, Ghysdael J, Wang S, Speck NA, Owen MJ. (1994) Cooperative binding of Ets-1 and core binding factor to DNA. Mol. Cell. Biol. 14: 840850 .

25. Wurster AL, Siu G, Leiden JM, Hedrick SM. (1994) Elf-1 binds to a critical element in a second CD4 enhancer. Mol. Cell. Biol. 14: 6452-6463 [published erratum appears in Mol. Cell. Biol. (1994) 14: 8493].
26. Ernst P, Hahm K, Smale ST. (1993) Both LyF-1 and an Ets protein interact with a critical promoter element in the murine terminal transferase gene. Mol. Cell. Biol. 13: 2982-2992.

27. Heydemann A, Juang G, Hennesy K, Parmacek M, Simon C. (1996) The myeloid cell-specific c-fes promoter is regulated by Spl, PU.l and a novel transcription factor. Mol. Cell. Biol. 16: 1676-1686.

28. Leiden JM, Wang C-Y, Petryniak B, et al. (1992) A novel Ets-related transcription factor, elf-1, binds to human immunodeficiency virus type 2 regulatory elements that are required for inducible trans activation in T cells. J. Virol. 66: 5890-5897.

29. Markovitz DM, Smith MJ, Hilfinger J, et al. (1992) Activation of the human immunodeficiency virus type 2 enhancer is dependent on purine box and kappa B regulatory elements. J. Virol. 66: 54795484.

30. Hilfinger JM, Clark N, Smith M, Robinson K, Markovitz DM. (1993) Differential regulation of the human immunodeficiency virus type 2 enhancer in monocytes at various stages of differentiation. J. Virol. 67: 4448-4453.

31. Kuratani S, Martin J, Wawersik S, et al. (1994) The expression pattern of the chick homeobox gene $M H o x$ suggests a role in patterning of the limbs and face in compartmentalization of somites. Dev. Biol. 161: 357-369.

32. Morrisey EE, Ip HS, Lu MM, Parmacek MS. (1996) GATA-6: a zinc finger transcription factor that is expressed in multiple cell lineages derived from lateral mesoderm. Dev. Biol. 177: 309-322.

33. Davis N, Roussel M. (1996) Cloning and expression of the murine Elf-1 c-DNA. Gene 171: 265269.

34. Wang CY, Petryniak B, Thompson CB, Kaelin WG, Leiden JM. (1993) Regulation of the Etsrelated transcription factor Elf- 1 by binding to the retinoblastoma protein. Science 260: 1330-1335.

35. Thompson CB, Wang CY, Ho IC, et al. (1992) cis-acting sequences required for inducible interleukin-2 enhancer function bind a novel Ets-related protein, Elf-1. Mol. Cell. Biol. 12: 1043-1053.

36. Wilkinson D, Neale G, Mao S, Naeve C, Goorha R. (1997) Elf-2, a rhombotin-2 binding Ets transcription factor: discovery and potential role in $\mathrm{T}$ cell leukemia. Leukemia 11: 86-96.

37. Oettgen P, Akbarali Y, Boltax J, et al. (1996) Characterization of NERF, a novel transcription factor related to the Ets factor ELF-1. Mol. Cell. Biol. 16: 5091-5106.

38. Miyazaki $Y$, Sun $X$, Uchida $H$, Zhang J, Nimer S. (1996) MEF, a novel transcription factor with an Elf-1 like DNA binding domain but distinct transcriptional activating properties. Oncogene 17: 1721-1729.

39. Tymms MJ, Ng AY, Thomas RS, Schutte BC, Zhou J, Eyre HJ, Sutherland GR, Seth A, Rosenberg M, Papas T, Debouck C, Kola I. (1997) A novel epithelial-expressed ETS gene, ELF3: human and 
murine cDNA sequences, murine genomic organization, human mapping to lq 32.2 and expression in tissues and cancer. Oncogene 13: 24492462.

40. Oettgen P, Alani RM, Barcinski MA, Brown L, Akbarali Y, Boltax J, Kunsch C, Munger K, Libermann TA. (1997) Isolation and characterization of a novel epithelium-specific transcription factor, ESE-1, a member of the ets family. Mol. Cell. Biol. 17: 4419-4433.

41. Chang CH, Scott GK, Kuo WL, Xiong X, Suzdaltseva Y, Park JW, Sayre P, Erny K, Collins C, Gray JW, Benz CC. (1997) ESX: a structurally unique Ets overexpressed early during human breast tumorigenesis. Oncogene 14: 1617-1622.

42. Andreoli JM, Jang S-I, Chung E, Coticchia CM, Steinert PM, Markova NG. (1997) The expression of a novel, epithelium-specific ets transcription factor is restricted to the most differentiated layers in the epidermis. Nucl. Acids Res. 25: 4287-4295.

43. Zhang M, Maass N, Magit D, Sager R. (1997)
Transactivation through Ets and Apl transcription sites determines the expression of the tumor-suppressing gene Maspin. Cell Growth Differ. 8: 179176.

44. Gordon JI, Schmidt GH, Roth KA. (1992) Studies of intestinal stem cells using normal, chimeric, and transgenic mice. Review. FASEB J. 6: 30393050.

45. Fuchs E. (1993) Epidermal differentiation and keratin gene expression. J. Cell Sci. Suppl. 17: 197208.

46. Bassuk AG, Leiden JM. (1995) A direct physical association between ETS and AP-1 transcription factors in normal human $\mathrm{T}$ cells. Immunity 3: 223237.

47. Bassuk A, Anandappa R, Leiden J. (1997) Physical interactions between Ets and NF- $\kappa \mathrm{b} / \mathrm{NFAT}$ proteins play an important role in their cooperative activation of the human immunodeficiency virus enhancer in T cells. J. Virol. 71: 3563-3573. 